\title{
OPTIMALISASI PENENTUAN JURUSAN MELALUI PERBANDINGAN METODE MOORA-WASPAS
}

\author{
Ullya Mega Wahyuni ${ }^{1}$, Afriyanti Dwi Kartika ${ }^{2}$ \\ ${ }^{1,2}$ Jurusan Sistem Informasi Fakultas Teknologi Informasi Universitas Andalas \\ Limau Manis, Pauh, Kota Padang, Sumatera Barat 25175 \\ 11ullyamegawahyuni@it.unand.ac.id \\ ${ }^{2}$ afriyantidwikartika@it.unand.ac.id
}

\begin{abstract}
Abstrak - Penyerapan tenaga kerja dari lulusan Sekolah Menengah Kejuruan (SMK) lebih rendah dibandingkan lulusan tingkat pendidikan lainnya. Hal ini terlihat dari banyaknya tingkat pengangguran dari lulusan SMK sebesar 13,55 \%. Untuk meningkatkan kompetensi lulusan SMK salah satunya dengan pemilihan jurusan yang tepat. Pemilihan jurusan yang tepat dapat membantu meningkatkan kompetensi keahlian siswa dan memberikan kenyamanan selama proses belajar mengajar. Keputusan pemilihan jurusan yang dilakukan siswa saat ini berdasarkan pengaruh orang lain atau berdasarkan jurusan yang paling banyak diminati. Hal ini akan menyebakan ketidaksesuaikan penempatan jurusan dengan kemampuan calon siswa sehingga materi yang diberikan selama di dalam kelas akan sulit diterima. Untuk membantu penentu keputusan dalam menentukan keputusan maka hasil rekomendasi dari sistem pendukung keputusan (SPK) dapat dijadikan sebagai acuan pemilihan jurusan bagi calon siswa. Data yang akan diuji terdiri dari tujuh kriteria dengan enam alternatif, data tersebut di analisis dengan metode Weight Aggregated Sum Product Assesment (WASPAS) dan metode Multi Objective Optimization on the basis of Ratio Analysis (MOORA). Hasil pengujian dari kedua metode memberikan rekomendasi yang sama yaitu terpilihnya Jurusan Teknik Instalansi Tenaga Listrik sebagai nilai prefensi tertinggi yang sesuai dengan bakat dan minat calon siswa berdasarkan data uji. Jika dilihat dari waktu eksekusi analisa perhitungan, maka metode WASPAS membutuhkan waktu eksekusi yang lebih cepat dibandingkan metode MOORA. Akurasi dari kedua metode yang digunakan memberikan hasil yang sama yaitu 50\%. Jadi bisa disimpulkan bahwa metode WASPAS maupun MOORA cukup baik dan memberikan solusi atas permasalahan dalam menilai dan mengevaluasi jurusan yang sesuai dengan bakat dan minat calon siswa.
\end{abstract}

Kata kunci-Sistem Pengambilan Keputusan, WASPAS, MOORA, Pemilihan Jurusan.

\section{PENDAhUluan}

Pendidikan merupakan aspek penting untuk menjaga kelangsungan hidup setiap individu dan sebagai fondasi kemajuan bangsa [1]. Pengembangan pendidikan menjadi suatu keharusan dan kewajaran karena pendidikan berperan dalam pengembangan sumber daya manusia (SDM) unggul [2]. Selain itu pendidikan merupakan produk budaya suatu bangsa yang tumbuh dan terus berkembang menyesuaikan tuntutan perubahan di masyarakat [3]. Budaya literasi diperlukan untuk mewujudkan peran generasi muda dalam pembangunan negara [4].

Saat ini pemerintahan Indonesia terus mendorong peningkatan kapasitas SDM salah satunya melakukan revitalisasi Sekolah Menengah Kejuruan (SMK) secara komprehensif. Revitalisasi dilakukan untuk menghasilkan SDM unggul dan siap menghadapi tantangan nasional dan global. SDM unggul yang dihasilkan dari pelayanan pendidikan SMK yang berkualitas diyakini dapat mendukung kearifan lokal pada sektor pembangunan ekonomi sehingga mendorong peningkatan industri dengan berwirausaha.

Namun demikian, penyerapan tenaga kerja dari lulusan SMK lebih rendah dibandingkan lulusan Sekolah Menengah Atas (SMA) maupun tingkatan pendidikan lainnya. Berdasarkan data statistik yang dirilis pada tanggal 05 November 2020 oleh Badan Pusat Statistik, pengangguran di Indonesia didominasi dari lulusan SMK. Jika dilihat secara rinci dari data tingkat pengangguran terbuka (TPT), jumlah pengangguran lulusan SMK sebesar 13,55 \%, SMA sebesar $9,86 \%$ dan yang paling rendah lulusan Sekolah Dasar (SD) sebesar 3,61\% .

Salah satu faktor penyebab rendahnya serapan lulusan SMK adalah tidak sesuainya kualitas lulusan dengan standar industri. Pendidikan vokasi perlu dilakukan link and match dengan dunia industri. Mengidentifikasi minat dan bakat calon siswa pada pemilihan jurusan juga bisa dilakukan sebagai 
upaya peningkatan kualitas lulusan. Pemilihan jurusan yang tepat membantu meningkatkan kompetensi siswa dan memberikan kenyamaan selama proses belajar mengajar [5].

SMKN 1 Sungai Rumbai memiliki enam kompetensi keahlian yaitu teknik audio video, teknik desain pemodelan informasi bangunan, teknik perancangan gambar mesin, teknik instalasi tenaga listrik, teknik pengelasan, dan teknik otomasi industri. Proses pemilihan jurusan saat ini dinilai masih belum efektif karena banyak calon siswa memilih jurusan berdasarkan masukan orang lain atau jurusan yang paling banyak diminati. Hal ini tentunya akan menyebabkan ketidaksesuaian antara jurusan yang dipilih dengan kemampuan calon siswa. Jika kondisi ini dibiarkan tentunya akan berpengaruh terhadap kompetensi keahlian siswa yang rendah karna sulitnya siswa menerima materi yang diberikan selama di dalam kelas. Dari permasalahan tersebut, maka dibutuhkan sebuah sistem pendukung keputusan (SPK) yang dapat membantu penentu keputusan dalam memberikan keputusan berdasarkan hasil rekomendasi. Metode yang digunakan dalam proses menghasilkan keputusan ini adalah kombinasi metode Multi-Objective Optimization on the basis of Ratio Analysis (MOORA) dan Weight Aggregated Sum Product Assesment (WASPAS). Metode MOORA digunakan untuk menentukan bobot kriteria dan WASPAS digunakan untuk membandingkan alternatif.

Penggunaan metode WASPAS pada penelitian sebelumnya dilakukan pada seleksi anggota PPK Pilkada dengan menggunakan delapan kriteria dan sepuluh alternatif. Dari hasil analisa tersebut diperoleh rekomendasi anggota panitia pemilihan kecamatan dengan nilai tertinggi sebesar 0,9202 [6]. Penelitian dengan metode MOORA juga pernah dilakukan dalam pemilihan karyawan tetap pada Trinity Teknologi dengan menggunakan empat kriteria dan lima alternatif. Hasil akhir dari analisa ini adalah rekomendasi nama calon pegawai yang bisa dijadikan karyawan tetap dengan nilai tertinggi sebesar 0.4977 [7]. Pada penelitian lainnya untuk pemilihan jurusan sudah diterapkan dengan metode PROMETHEE. Hasil dari metode ini memberikan keputusan berupa rekomendasi jurusan yang sesuai dengan kemampuan calon siswa. Namun metode PROMETHEE memiliki kelemahan dalam memberikan pemilihan alternatif secara optimal dan memerlukan fungsi tambahan [8].

Dari beberapa metode yang sudah diujikan, maka peneliti mencoba menggunakan metode WASPAS dan MOORA dengan fokus masing-masing yang akan membantu dalam pemilihan jurusan. Hasil dari kedua metode tersebut dilakukan perbandingan untuk menghasilkan keputusan terbaik.

\section{Metodologi PENELITIAN}

Pada penelitian ini, tahapan setiap proses pengambilan keputusan dengan kombinasi metode WASPAS-MOORA dapat dilihat pada Gambar 1 .

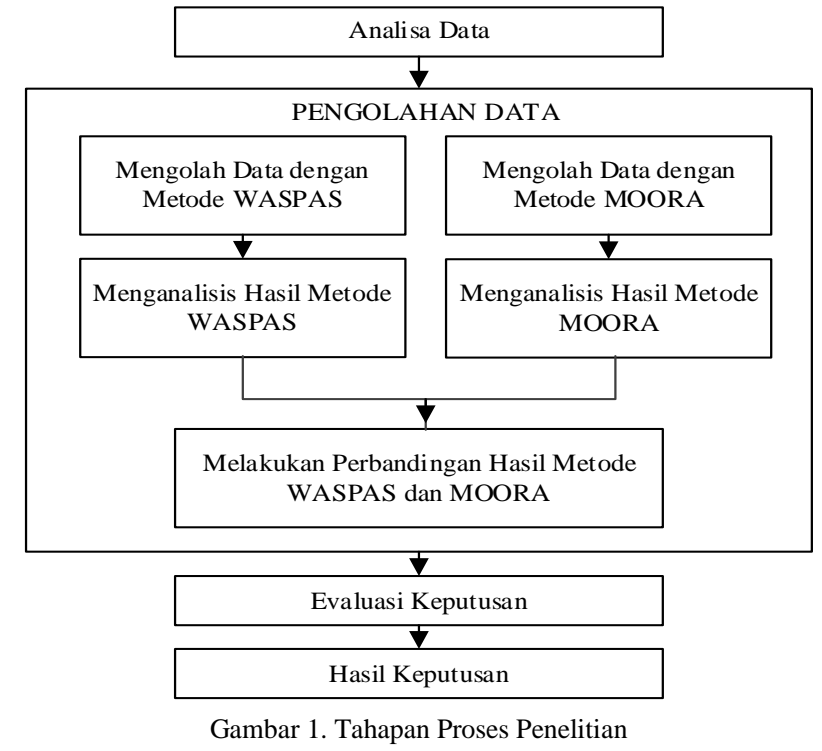

\section{A. Analisa Data}

Analisa data digunakan untuk mengekstrak informasi dari data yang dikumpulkan untuk menghasilkan sebuah keputusan. Data yang digunakan berupa data kriteria dan data alternatif. Data tersebut Tabel 1 menunjukkan kriteria yang digunakan dan Tabel II menunjukkan data alternatif.

TABEL I

KRITERIA YANG DIGUNAKAN

\begin{tabular}{|c|c|c|c|c|c|}
\hline Kode & Kriteria & Deskripsi & Nilai & Jenis & Bobot \\
\hline K1 & Jumlah Pengajar & $\begin{array}{l}>10 \text { Guru } \\
5-9 \text { Guru } \\
1-4 \text { Guru }\end{array}$ & $\begin{array}{l}1 \\
0,75 \\
0,5\end{array}$ & Benefit & 1,5 \\
\hline $\mathrm{K} 2$ & $\begin{array}{l}\text { Jumlah } \\
\text { Siswa }\end{array}$ & $\begin{array}{l}>=30 \\
20-29 \\
10-19 \\
<=9\end{array}$ & $\begin{array}{l}1 \\
0,75 \\
0,5 \\
0,25\end{array}$ & Benefit & 1 \\
\hline K3 & Fasilitas & $\begin{array}{l}\text { Memadai (M) } \\
\text { Cukup Memadai (C) } \\
\text { Tidak Memadai (TM) }\end{array}$ & $\begin{array}{l}0,75 \\
0,5 \\
0,25\end{array}$ & Benefit & 1,5 \\
\hline K4 & $\begin{array}{l}\text { Prestasi } \\
\text { Jurusan }\end{array}$ & $\begin{array}{l}>=5 \\
2-4 \\
<=1\end{array}$ & $\begin{array}{l}0,75 \\
0,5 \\
0,25\end{array}$ & Benefit & 1,5 \\
\hline K5 & $\begin{array}{l}\text { Rata-rata } \\
\text { Nilai } \\
\text { Kompetensi }\end{array}$ & $\begin{array}{l}>=90 \\
75-89 \\
66-74 \\
<=65\end{array}$ & $\begin{array}{l}1 \\
0,75 \\
0,5 \\
0,25\end{array}$ & Benefit & 2 \\
\hline K6 & $\begin{array}{l}\text { Nilai Tes } \\
\text { Bakat }\end{array}$ & $\begin{array}{l}>=90 \\
75-89 \\
66-74 \\
<=65\end{array}$ & $\begin{array}{l}1 \\
0,75 \\
0,5 \\
0,25\end{array}$ & Benefit & 1,5 \\
\hline K7 & $\begin{array}{l}\text { Minat } \\
\text { Siswa }\end{array}$ & $\begin{array}{l}\text { Suka Sekali (SS) } \\
\text { Suka (S) } \\
\text { Biasa Saja (BS) } \\
\text { Kurang Suka (KS) } \\
\text { Tidak Suka (TS) }\end{array}$ & $\begin{array}{l}1 \\
0,75 \\
0,5 \\
0,25 \\
0\end{array}$ & Benefit & 1 \\
\hline
\end{tabular}


TABEL II

DATA ALTERNATIF

\begin{tabular}{cl}
\hline No & Jurusan \\
\hline 1 & Teknik audio video \\
2 & Teknik desain pemodelan informasi bangunan \\
3 & Teknik perancangan gambar mesin \\
4 & Teknik instalasi tenaga listrik \\
5 & Teknik pengelasan \\
6 & Teknik otomasi industri
\end{tabular}

\section{B. Pengolahan Data}

Setelah didapatkan kriteria dan alternatif yang digunakan maka proses selanjutnya adalah melakukan penghitungan dengan metode WASPAS dan MOORA. Setiap metode memiliki tahapan yang berbeda sehingga hasil dari proses pengolahan data kedua metode tersebut juga berbeda. Hasil akhir dari masing-masing metode akan dilakukan perbandingan sebelum masuk tahap evaluasi untuk menghasilkan sebuah keputusan.

MOORA merupakan suatu teknik yang digunakan secara bersamaan untuk optimalisasi dua atau lebih nilai atribut yang saling bertentangan [9]. MOORA lebih fleksibel dan mudah untuk dipahami saat proses evaluasi dengan memisahkan bagian subjektif kedalam kriteria bobot keputusan dengan beberapa atribut pengambilan keputusan [10]. Berikut tahapan pengolahan data dengan metode MOORA [11]:

1. Mengidentifikasi alternatif dan kriteria yang digunakan

2. Membuat matriks keputusan dari data uji

$$
x=\left[\begin{array}{ccc}
x 11 & x 12 & x 1 n \\
x 21 & x 22 & x 2 n \\
x m 1 & x m 2 & x m n
\end{array}\right]
$$

3. Normalisasi Matriks

Normalisasi mariks tujuannya adalah menggabungkan setiap komponen matriks sehingga komponen pada matriks nilainya seragam.

$$
x i j=\frac{x i j}{\sqrt{\sum_{i=1}^{m} X^{2}} i j}
$$

\section{Prefensi nilai $Y i$}

Untuk optimalisasi multi-objektif, pada kasus maksimasi (benefit) maka kinerja yang dinormalisasi ditambahkan begitu juga sebaliknya untuk kasus minimasi (cost).

$$
Y i=\sum_{j=1}^{g} W j X i j-\sum_{j=g+1}^{n} W j X i j
$$

Keterangan:

$\mathrm{g}=$ Jumlah atribut benefit,

(n-g) = Jumlah atribut cost, dan

$Y i \quad=$ Nilai prefensi hasil optimalisasi

$W_{J} \quad=$ Bobot atribut

5. Perangkingan $(y i)$
Positif dan negatifnya nilai $y i$ tergantung dari total maksimum dan minimum pada matriks keputusan. Nilai $y i$ positif dipilih sebagai alternative terbaik sedangkan nilai $y i$ negatif sebagai alternative terendah.

Metode WASPAS sangat efektif dan dapat diterapkan untuk menyelesaiakan permasalahan MCDM (Multi Criteria Decision Making) [12]. WASPAS merupakan kombinasi dari WSM-WPM yang digunakan untuk memecahkan sejumlah besar masalah pengambilan keputusan dengan memanfaatkan nilai skor prefensi [13]. Pengolahan data dengan menggunakan metode WASPAS terdapat beberapa langkah utama, yaitu [14]:

1. Membuat matriks keputusan.

$$
x=\left[\begin{array}{ccc}
x 11 & x 12 & x 1 n \\
x 21 & x 22 & x 2 n \\
x m 1 & x m 2 & x m n
\end{array}\right]
$$

2. Melakukan normalisasi terhadap matriks keputusan. Untuk kriteria benefit, maka digunakan rumus:

$$
R i j=\frac{x i j}{M a x}_{x i j}
$$

Untuk kriteria cost, maka digunakan rumus:

$$
R i j=\frac{\operatorname{Min}_{x i j}}{X i j}
$$

3. Menghitung nilai prefensi $Q i$

$$
Q_{i}=0,5 \sum_{j=0}^{n} R_{I J} W j+0,5 \Pi_{i=1}\left(R_{I J}\right) W j
$$

\section{HASIL DAN PEMBAHASAN}

\section{A. Perhitungan MOORA}

Setelah langkah pertama yaitu identifikasi kriteria dan alternatif selesai dilakukan, maka proses selanjutnya adalah membuat matriks keputusan dari data uji.

TABEL III

DATA UJI

\begin{tabular}{clllllll}
\hline Alternatif & \multicolumn{7}{c}{ Kriteria } \\
\cline { 2 - 8 } & K1 & K2 & K3 & K4 & K5 & K6 & K7 \\
\hline A1 & 20 & 35 & M & 2 & 75 & 70 & SS \\
\hline A2 & 18 & 35 & CM & 1 & 75 & 65 & S \\
\hline A3 & 15 & 25 & CM & 1 & 70 & 65 & BS \\
\hline A4 & 15 & 25 & M & 2 & 90 & 90 & S \\
\hline A5 & 12 & 25 & M & 2 & 70 & 60 & TS \\
\hline A6 & 18 & 35 & CM & 1 & 60 & 50 & KS \\
\hline
\end{tabular}

Data uji yang ada pada Tabel III disesuaikan dengan nilai yang diberikan pada setiap sub kriteria. Tabel IV menunjukkan hasil matriks keputusan. 
TABEL IV

MATRIKS KEPUTUSAN

\begin{tabular}{llllllll}
\hline Alternatif & \multicolumn{7}{c}{ Kriteria } \\
\cline { 2 - 8 } & $\mathbf{K 1}$ & $\mathbf{K 2}$ & $\mathbf{K 3}$ & $\mathbf{K 4}$ & $\mathbf{K 5}$ & $\mathbf{K 6}$ & $\mathbf{K 7}$ \\
\hline Audio Video & 1 & 1 & 0,75 & 0,75 & 0,75 & 0,5 & 1 \\
\hline $\begin{array}{l}\text { Desain Pemodelan } \\
\text { Informasi Bangunan }\end{array}$ & 1 & 1 & 0,5 & 0,5 & 0,75 & 0,25 & 0,75 \\
\hline $\begin{array}{l}\text { Perancangan Gambar } \\
\text { Mesin }\end{array}$ & 1 & 0,75 & 0,5 & 0,5 & 0,5 & 0,25 & 0,75 \\
\hline Instalasi Tenaga Listrik & 1 & 0,75 & 0,75 & 0,75 & 1 & 1 & 0,5 \\
\hline Pengelasan & 1 & 0,75 & 0,75 & 0,75 & 0,5 & 0,25 & 0 \\
\hline Otomasi Industri & 1 & 1 & 0,5 & 0,5 & 0,25 & 0,25 & 0,25 \\
\hline
\end{tabular}

Tahapan selanjutnya adalah melakukan normalisasi matriks keputusan dengan menggunakan rumus (2).

$$
\begin{aligned}
& A_{\text {lternatif } 1:} \\
& K_{11}=\frac{1}{\sqrt{1^{2}+1^{2}+1^{2}+1^{2}+1^{2}+1^{2}}}=0.408 \\
& K_{21}=\frac{1}{\sqrt{1^{2}+1^{2}+0.75^{2}+0.75^{2}+0.75^{2}+1^{2}}}=0.462 \\
& K_{61}=\frac{0.5}{\sqrt{0.5^{2}+0.25^{2}+0.25^{2}+1^{2}+0.25^{2}+0.25^{2}}}=0.408 \\
& K_{71}=\frac{1}{\sqrt{1^{2}+0.75^{2}+0.75^{2}+0.5^{2}+0^{2}+0.25^{2}}}=0.641
\end{aligned}
$$

A lternatif 2:

$$
\begin{aligned}
& K_{12}=\frac{1}{\sqrt{1^{2}+1^{2}+1^{2}+1^{2}+1^{2}+1^{2}}}=0.408 \\
& K_{22}=\frac{1}{\sqrt{1^{2}+1^{2}+0.75^{2}+0.75^{2}+0.75^{2}+1^{2}}}=0.462 \\
& K_{62}=\frac{0.25}{\sqrt{0.5^{2}+0.25^{2}+0.25^{2}+1^{2}+0.25^{2}+0.25^{2}}}=0.204 \\
& K_{72}=\frac{0.75}{\sqrt{1^{2}+0.75^{2}+0.75^{2}+0.5^{2}+0^{2}+0.25^{2}}}=0.480
\end{aligned}
$$

$$
\begin{aligned}
& \mathrm{A}_{\text {lternatif } 3:} \\
& K_{13}=\frac{1}{\sqrt{1^{2}+1^{2}+1^{2}+1^{2}+1^{2}+1^{2}}}=0.408 \\
& K_{23}=\frac{0.75}{\sqrt{1^{2}+1^{2}+0.75^{2}+0.75^{2}+0.75^{2}+1^{2}}}=0.346 \\
& : \\
& K_{63}=\frac{0.25}{\sqrt{0.5^{2}+0.25^{2}+0.25^{2}+1^{2}+0.25^{2}+0.25^{2}}}=0.204 \\
& K_{73}=\frac{0.75}{\sqrt{1^{2}+0.75^{2}+0.75^{2}+0.5^{2}+0^{2}+0.25^{2}}}=0.480
\end{aligned}
$$

$$
\begin{aligned}
& \mathrm{A}_{\text {lternatif } 4:} \\
& K_{14}=\frac{1}{\sqrt{1^{2}+1^{2}+1^{2}+1^{2}+1^{2}+1^{2}}}=0.408 \\
& K_{24}=\frac{0.75}{\sqrt{1^{2}+1^{2}+0.75^{2}+0.75^{2}+0.75^{2}+1^{2}}}=0.346 \\
& : \\
& K_{64}=\frac{1}{\sqrt{0.5^{2}+0.25^{2}+0.25^{2}+1^{2}+0.25^{2}+0.25^{2}}}=0.816
\end{aligned}
$$

$$
K_{74}=\frac{0.5}{\sqrt{1^{2}+0.75^{2}+0.75^{2}+0.5^{2}+0^{2}+0.25^{2}}}=0.320
$$

$$
\begin{aligned}
& \mathrm{A}_{\text {lternatif } 5:} \\
& K_{15}=\frac{1}{\sqrt{1^{2}+1^{2}+1^{2}+1^{2}+1^{2}+1^{2}}}=0.408 \\
& K_{25}=\frac{0.75}{\sqrt{1^{2}+1^{2}+0.75^{2}+0.75^{2}+0.75^{2}+1^{2}}}=0.346 \\
& : \\
& K_{65}=\frac{0.25}{\sqrt{0.5^{2}+0.25^{2}+0.25^{2}+1^{2}+0.25^{2}+0.25^{2}}}=0.204 \\
& K_{75}=\frac{0}{\sqrt{1^{2}+0.75^{2}+0.75^{2}+0.5^{2}+0^{2}+0.25^{2}}}=0.000
\end{aligned}
$$

$$
\begin{aligned}
& \mathrm{A}_{\text {lternatif } 6:} \\
& K_{16}=\frac{1}{\sqrt{1^{2}+1^{2}+1^{2}+1^{2}+1^{2}+1^{2}}}=0.408 \\
& K_{26}=\frac{1}{\sqrt{1^{2}+1^{2}+0.75^{2}+0.75^{2}+0.75^{2}+1^{2}}}=0.462 \\
& : \\
& K_{66}=\frac{0.25}{\sqrt{0.5^{2}+0.25^{2}+0.25^{2}+1^{2}+0.25^{2}+0.25^{2}}}=0.204 \\
& K_{76}=\frac{0.25}{\sqrt{1^{2}+0.75^{2}+0.75^{2}+0.5^{2}+0^{2}+0.25^{2}}}=0.160
\end{aligned}
$$

Hasil normalisasi secara keseluruhan terhadap tujuh kriteria dan enam alternatif ditunjukkan pada Tabel V.

TABEL V

NORMALISASI

\begin{tabular}{cccccccc}
\hline Alternatif & \multicolumn{7}{c}{ Kriteria } \\
\cline { 2 - 8 } & K1 & K2 & K3 & K4 & K5 & K6 & K7 \\
\hline A1 & 0.408 & 0.462 & 0.480 & 0.480 & 0.457 & 0.408 & 0.641 \\
\hline A2 & 0.408 & 0.462 & 0.320 & 0.320 & 0.457 & 0.204 & 0.480 \\
\hline A3 & 0.408 & 0.346 & 0.320 & 0.320 & 0.305 & 0.204 & 0.480 \\
\hline A4 & 0.408 & 0.346 & 0.480 & 0.480 & 0.610 & 0.816 & 0.320 \\
\hline A5 & 0.408 & 0.346 & 0.480 & 0.480 & 0.305 & 0.204 & 0.000 \\
\hline A6 & 0.408 & 0.462 & 0.320 & 0.320 & 0.152 & 0.204 & 0.160 \\
\hline & & & & & & &
\end{tabular}

Untuk melakukan optimalisasi, maka dilakukan perhitungan dengan menggunakan rumus (3). Sebelum dihitung nilai prefensi $Y i$, langkah selanjutnya adalah mengoptimalkan setiap nilai kriteria dengan cara mengalikan nilai bobot.

$$
\begin{aligned}
& \mathrm{K}_{\text {riteria 1: }} \\
& K_{11}=0.408 * 1.5=0.612 \\
& : \\
& K_{15}=0.408 * 1.5=0.612 \\
& K_{16}=0.408 * 1.5=0.612 \\
& \mathrm{~K}_{\text {riteria } 2:} \\
& K_{21}=0.462 * 1=0.462
\end{aligned}
$$


$K_{25}=0.346 * 1=0.346$

$K_{26}=0.462 * 1=0.462$

$\mathrm{K}_{\text {riteria 3: }}$

$K_{31}=0.480 * 1.5=0.721$

:

$K_{35}=0.480 * 1.5=0.721$

$K_{36}=0.320 * 1.5=0.480$

$\mathrm{K}_{\text {riteria 4: }}$

$K_{41}=0.480 * 1.5=0.721$

$K_{45}=0.480 * 1.5=0.721$

$K_{46}=0.320 * 1.5=0.480$

$\mathrm{K}_{\text {riteria 5: }}$

$K_{51}=0.457 * 2=0.915$

$K_{55}=0.305 * 2=0.610$

$K_{56}=0.152 * 2=0.305$

$\mathrm{K}_{\text {riteria 6: }}$

$K_{61}=0.408 * 1.5=0.612$

$K_{65}=0.204 * 1.5=0.306$

$K_{66}=0.204 * 1.5=0.306$

$\mathrm{K}_{\text {riteria 7: }}$

$K_{71}=0.641 * 1=0.641$

$K_{75}=0.000 * 1=0.000$

$K_{76}=0.160 * 1=0.160$

Prefensi nilai $Y i$ pada Tabel VI didapatkan dari optimalisasi total. Untuk data yang bertype benefit, maka nilai atribut bertanda positif dan jika data bertype cost maka nilai atribut bertanda negatif.

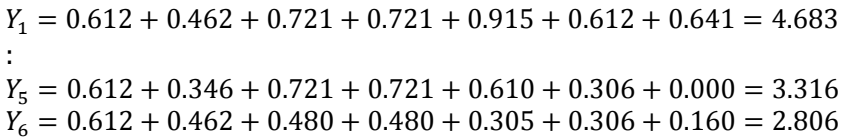

TABEL VI

PREFENSI NILAI $Y I$

\begin{tabular}{cccccccc}
\hline Nilai Yi & \multicolumn{7}{c}{ Kriteria } \\
\cline { 2 - 8 } & $\mathbf{K 1}$ & $\mathbf{K 2}$ & $\mathbf{K 3}$ & $\mathbf{K 4}$ & $\mathbf{K 5}$ & $\mathbf{K 6}$ & $\mathbf{K 7}$ \\
\hline$Y_{1}$ & 0.612 & 0.462 & 0.721 & 0.721 & 0.915 & 0.612 & 0.641 \\
\hline$Y_{2}$ & 0.612 & 0.462 & 0.480 & 0.480 & 0.915 & 0.306 & 0.480 \\
\hline$Y_{3}$ & 0.612 & 0.346 & 0.480 & 0.480 & 0.610 & 0.306 & 0.480 \\
\hline$Y_{4}$ & 0.612 & 0.346 & 0.721 & 0.721 & 1.220 & 1.225 & 0.320 \\
\hline$Y_{5}$ & 0.612 & 0.346 & 0.721 & 0.721 & 0.610 & 0.306 & 0.000 \\
\hline$Y_{6}$ & 0.612 & 0.462 & 0.480 & 0.480 & 0.305 & 0.306 & 0.160 \\
\hline
\end{tabular}

Langkah terakhir adalah melakukan perangkingan dari hasil optimalisasi. Nilai dengan prefensi tertinggi merupakan nilai alternatif terbaik dan begitu juga sebaliknya. Hasil perangkingan bisa dilihat pada Tabel VII.

TABEL VII

PERANGKINGAN

\begin{tabular}{lcc}
\hline Alternatif & Ranking & Nilai Optimalisasi \\
\hline Teknik Instalasi Tenaga Listrik & 1 & $Y_{4}=5.165$ \\
\hline Teknik Audio Video & 2 & $Y_{1}=4.683$ \\
\hline $\begin{array}{l}\text { Teknik Desain Pemodelan } \\
\text { Informasi Bangunan }\end{array}$ & 3 & $Y_{2}=3.737$ \\
\hline Teknik Perancangan Gambar Mesin & 4 & $Y_{3}=3.316$ \\
\hline Teknik Pengelasan & 5 & $Y_{5}=3.316$ \\
\hline Teknik Otomasi Industri & 6 & $Y_{6}=2.806$
\end{tabular}

Dari hasil perangkingan metode MOORA, bisa diketahui bahwa Jurusan Teknik Instalasi Tenaga Listrik merupakan jurusan terbaik yang direkomendasikan sesuai dengan bakat dan minat calon siswa. Hasil rekomendasi dari metode MOORA diambil dari hasil preferensi nilai tertinggi sebesar 5.165

\section{B. Perhitungan WASPAS}

Proses pertama pada metode WASPAS adalah membuat matriks keputusan dari data uji seperti yang ditunjukkan pada Tabel VIII.

TABEL VIII

MATRIKS KEPUTUSAN

\begin{tabular}{llllllll}
\hline \multirow{2}{*}{ Jurusan } & \multicolumn{7}{c}{ Kriteria } \\
\cline { 2 - 8 } & K1 & K2 & K3 & K4 & K5 & K6 & K7 \\
\hline Audio Video & 1 & 1 & 0,75 & 0,75 & 0,75 & 0,5 & 1 \\
\hline $\begin{array}{l}\text { Desain Pemodelan Informasi } \\
\text { Bangunan }\end{array}$ & 1 & 1 & 0,5 & 0,5 & 0,75 & 0,25 & 0,75 \\
\hline Perancangan Gambar Mesin & 1 & 0,75 & 0,5 & 0,5 & 0,5 & 0,25 & 0,75 \\
\hline Instalasi Tenaga Listrik & 1 & 0,75 & 0,75 & 0,75 & 1 & 1 & 0,5 \\
\hline Pengelasan & 1 & 0,75 & 0,75 & 0,75 & 0,5 & 0,25 & 0 \\
\hline Otomasi Industri & 1 & 1 & 0,5 & 0,5 & 0,25 & 0,25 & 0,25 \\
\hline
\end{tabular}

Kemudian menentukan nilai maksimum dan minimum dari setiap kriteria berdasarkan matriks keputusan.

TABEL IX

Nilai MaKSimal dan Minimal

\begin{tabular}{lccccccc}
\hline \multirow{3}{*}{ Alternatif } & \multicolumn{7}{c}{ Kriteria } \\
\cline { 2 - 8 } & K1 & K2 & K3 & K4 & K5 & K6 & K7 \\
\hline Max & 1 & 1 & 0,8 & 0,8 & 1 & 1 & 1 \\
\hline Min & 1 & 0,8 & 0,5 & 0,5 & 0,3 & 0,3 & 0 \\
\hline
\end{tabular}

Setelah itu dilakukan normalisasi dengan menghitung nilai Rij terhadap nilai maksimal dan minimal matriks keputusan yang ada pada Tabel IX. Untuk kriteria dengan jenis benefit dapat menggunakan rumus (5) dan untuk jenis cost 
menggunakan rumus (6). Maka nilai hasil normalisasi matriks dapat dilihat pada Tabel X.

TABEL X

NORMALISASI MATRIKS WASPAS

\begin{tabular}{clllllll}
\hline Alternatif & \multicolumn{8}{c}{ Kriteria } \\
\cline { 2 - 9 } & K1 & K2 & K3 & K4 & K5 & K6 & K7 \\
\hline A1 & 1 & 1 & 1 & 1 & 0.8 & 0.5 & 1 \\
\hline A2 & 1 & 1 & 0.7 & 0.667 & 0.8 & 0.3 & 0.8 \\
\hline A3 & 1 & 0.8 & 0.7 & 0.667 & 0.5 & 0.3 & 0.8 \\
\hline A4 & 1 & 0.8 & 1 & 1 & 1 & 1 & 0.5 \\
\hline A5 & 1 & 0.8 & 1 & 1 & 0.5 & 0.3 & 0 \\
\hline A6 & 1 & 1 & 0.7 & 0.667 & 0.3 & 0.3 & 0.3 \\
\hline
\end{tabular}

Langkah terakhir adalah menghitung nilai prefensi $(Q i)$ dari nilai normalisasi matriks dengan menggunakan rumus (7). Nilai prefensi $(Q i)$ secara keseluruhan bisa dilihat pada Tabel 11.

$$
\begin{array}{r}
Q_{i}=\left(0.5 \sum(1 * 1.5)+(1 * 1)+(1 * 1.5)+(1 * 1.5)+(0.8 * 2)+(0.5 * 1.5)+(1 * 1)\right) \\
+\left(0.5 \prod 1^{\left.1.5 * 1^{1} * 1^{1.5} * 1^{1.5} * 0.8^{2} * 0.5^{1.5} * 1^{1}\right)}=7.333\right.
\end{array}
$$

$$
\begin{aligned}
& Q_{2}=\left(0.5 \sum(1 * 1.5)+(1 * 1)+(0.7 * 1.5)+(0.667 * 1.5)+(0.8 * 2)+(0.3 * 1.5)+(0.8\right. \\
&* 1))+\left(0.5 \prod 1^{1.5} * 1^{1} * 0.7^{1.5} * 0.667^{1.5} * 0.8^{2} * 0.3^{1.5} * 0.8^{1}\right) \\
&=5.826
\end{aligned}
$$

$$
\begin{array}{r}
Q_{5}=\left(0.5 \sum(1 * 1.5)+(0.8 * 1)+(1 * 1.5)+(1 * 1.5)+(0.5 * 2)+(0.3 * 1.5)+(0 * 1)\right) \\
+\left(0.5 \prod 1^{1.5} * 0.8^{1} * 1^{1.5} * 1^{1.5} * 0.5^{2} * 0.3^{1.5} * 0^{1}\right)=5.375
\end{array}
$$

$$
\begin{array}{r}
Q_{6}=\left(0.5 \sum(1 * 1.5)+(1 * 1)+(0.7 * 1.5)+(0.667 * 1.5)+(0.3 * 2)+(0.3 * 1.5)+(0.3\right. \\
* 1))+\left(0.5 \prod 1^{1.5} * 1^{1} * 0.7^{1.5} * 0.667^{1.5} * 0.3^{2} * 0.3^{1.5} * 0.3^{1}\right)
\end{array}
$$

TABEL XI

HASIL PREFERENSI METODE WASPAS

\begin{tabular}{lcc}
\hline \multicolumn{1}{c}{ Alternatif } & Ranking & Nilai Optimalisasi \\
\hline Teknik Instalasi Tenaga Listrik & 1 & 7.750 \\
\hline Teknik Audio Video & 2 & 7.333 \\
\hline $\begin{array}{l}\text { Teknik Desain Pemodelan } \\
\text { Informasi Bangunan }\end{array}$ & 3 & 5.826 \\
\hline Teknik Pengelasan & 4 & 5.375 \\
\hline $\begin{array}{l}\text { Teknik Perancangan Gambar } \\
\text { Mesin }\end{array}$ & 5 & 5.169 \\
\hline Teknik Otomasi Industri & 6 & 4.576 \\
\hline
\end{tabular}

Dari hasil prefensi metode WASPAS, bisa diketahui bahwa Jurusan Teknik Instalasi Tenaga Listrik merupakan jurusan terbaik yang direkomendasikan sesuai dengan bakat dan minat calon siswa. Hasil rekomendasi dari metode WASPAS diambil dari Hasil Preferensi nilai tertinggi sebesar 7.750.

\section{Komparasi Metode WASPAS dan MOORA}

Perbandingan metode WASPAS dan MOORA dari hasil proses analisa perhitungan dapat dilihat pada Tabel XII.

TABEL XII

KOMPARASI METODE WASPAS DAN MOORA

\begin{tabular}{cccccc}
\hline \multicolumn{3}{c}{ WASPAS } & \multicolumn{3}{c}{ MOORA } \\
\hline Alternatif & Skor & Ranking & Alternatif & Skor & Ranking \\
\hline $\mathrm{A}_{4}$ & 7.750 & 1 & $\mathrm{~A}_{4}$ & 5.165 & 1 \\
\hline $\mathrm{A}_{1}$ & 7.333 & 2 & $\mathrm{~A}_{1}$ & 4.683 & 2 \\
\hline $\mathrm{A}_{2}$ & 5.826 & 3 & $\mathrm{~A}_{2}$ & 3.737 & 3 \\
\hline $\mathrm{A}_{5}$ & 5.375 & 4 & $\mathrm{~A}_{3}$ & 3.316 & 4 \\
\hline $\mathrm{A}_{3}$ & 5.169 & 5 & $\mathrm{~A}_{6}$ & 3.316 & 5 \\
\hline $\mathrm{A}_{6}$ & 4.576 & 6 & $\mathrm{~A}_{5}$ & 2.806 & 6 \\
\hline
\end{tabular}

Hasil akhir perhitungan menunjukkan bahwa WASPAS dan MOORA memberikan rekomendasi alternatif terbaik yang sama berdasarkan nilai prefensi tertinggi. Sedangkan untuk tiga alternatif terendah, WASPAS dan MOORA memberikan rekomendasi yang berbeda.

\section{Akurasi Metode WASPAS dan MOORA}

Berdasarkan hasil perbandingan dari metode MOORA dan WASPAS yang ditunjukkan pada Tabel XII, ditemukan perbedaan hasil peringkat untuk tiga alternatif terendah. Temuan presisi untuk kedua metode tersebut sebagai berikut:

1. WASPAS terdapat 3 pilihan jurusan yang berbeda dari hasil perangkingan WASPAS, jadi akurasi peringkat WASPAS sama dengan: $\frac{3}{6} 100 \%=50 \%$

2. MOORA terdapat 3 pilihan jurusan yang berbeda dari hasil perangkingan MOORA, jadi akurasi peringkat MOORA sama dengan: $\frac{3}{6} 100 \%=50 \%$

\section{KESIMPULAN}

Berdasarkan hasil proses analisa data menggunakan metode WASPAS dan MOORA, maka dapat diambil kesimpulan bahwa metode WASPAS dan MOORA memberikan rekomendasi yang sama yaitu berupa alternatif jurusan yang harus dipilih sesuai dengan bakat dan minat calon siswa. WASPAS dan MOORA merekomendasikan jurusan Teknik Instalansi Tenaga Listrik sebagai nilai prefensi tertinggi yang harus dipilih calon siswa berdasarkan data uji yang digunakan. Jika dilihat dari waktu eksekusi analisa perhitungan, maka metode WASPAS membutuhkan waktu eksekusi yang lebih cepat dibandingkan metode MOORA. Akurasi dari kedua metode yang digunakan memberikan hasil yang sama yaitu $50 \%$. Jadi bisa disimpulkan bahwa metode WASPAS maupun 
MOORA cukup baik dan memberikan solusi atas permasalahan dalam menilai dan mengevaluasi jurusan yang sesuai dengan bakat dan minat calon siswa.

\section{UCAPAN TERIMA KASIH}

Penulis mengucapkan terimakasih kepada semua pihak yang terlibat dalam penelitian optimalissasi penentuan jurusan teruatama pihak SMK 1 Sungai Rumbai dan rekan kerja yang membantu memberikan masukan sehingga penelitian ini bisa berjalan lancar sesuai dengan yang diinginkan.

\section{REFERENSI}

[1] Rahmadoni, J., Arifnur, A. A., \& Wahyuni, U. M. (2020). Penerapan schoology sebagai learning management system bagi guru SMAN 1 Sutera. Jurnal Hilirisasi IPTEKS, 3(2), 129-137.

[2] T. Saiful Akbar, "Manusia Dan Pendidikan Menurut Pemikiran Ibn Khaldun Dan John Dewey," J. Ilm. Didakt., Vol. 15, No. 2, Pp. 222-243, 2015.

[3] S. Adrianto, "Peranan Pendidikan Sebagai Transformasi Budaya," Stikomcki, Vol. 12, No. 1, Pp. 14-19, 2019.

[4] Wahyuni, Ullya Mega, Et Al. "Literasi Visual Media Edukasi Poster Terkait Covid-19 Pada Siswa Sma Di Kota Padang." Jurnal Hilirisasi Ipteks 4.1 (2021): 8291.

[5] A. Rufaidah, "Pengaruh Intelegensi Dan Minat Siswa Terhadap Putusan Pemilihan Jurusan," J. Ilm. Pendidik., Vol. 2, No. 2, P. 143, 2015.

[6] R. Yanto, "Analisis Perbandingan Keputusan Seleksi Anggota Ppk Pilkada Menggunakan Metode Saw Dan Waspas," Cogito Smart J., Vol. 6, No. 1, P. 83, 2020, Doi: 10.31154/Cogito.V6i1.224.83-96.

[7] A. Juanda And F. A. Sianturi, "Sistem Pendukung Keputusan Pemilihan Karyawan Tetap Pada Trinity Teknologi Nusantara Dengan Metode Moora," Jikomsi [Jurnal Ilmu Komput. Dan Sist. Informasi], Vol. 3, No. 3, Pp. 277-282, 2021.

[8] N. S. Atmaja, "Sistem Pendukung Keputusan Pemilihan Jurusan Menggunakan Metode Promethee (Studi Kasus : Smk Negeri 6 Medan)," Infotekjar J. Nas. Inform. Dan Teknol. Jar., Vol. 5, No. 2, Pp. 124133, 2021.

[9] S. Sutarno, M. Mesran, S. Supriyanto, Y. Yuliana, And A. Dewi, "Implementation Of Multi-Objective Optimazation On The Base Of Ratio Analysis (Moora) In Improving Support For Decision On Sales Location Determination," J. Phys. Conf. Ser., Vol. 1424, No. 1, Pp. 0-5, 2019, Doi: 10.1088/17426596/1424/1/012019.

[10] S. Fadli And K. Imtihan, "Implementation Of Moora
Method In Evaluating Work Performance Of Honorary Teachers," Sinkron, Vol. 4, No. 1, P. 128, 2019, Doi: 10.33395/Sinkron.V4i1.10192.

[11] I. Kamila And S. S. Helma, "Implementation Of Moora Method For Determining Prospective Smart Indonesia Program Funds Recipients," Int. J. Eng. Adv. Technol., Vol. 9, No. 2, Pp. 1920-1925, 2019, Doi: 10.35940/Ijeat.B2860.129219.

[12] D. Sergi And I. Ucal Sari, "Prioritization Of Public Services For Digitalization Using Fuzzy Z-Ahp And Fuzzy Z-Waspas," Complex Intell. Syst., Vol. 7, No. 2, Pp. 841-856, 2021, Doi: 10.1007/S40747-020-00239$\mathrm{Z}$.

[13] O. Onajite And S. A. Oke, "The Application Of Wsm, Wpm And Waspas Multicriteria Methods For Optimum Operating Conditions Selection In Machining Operations," J. Rekayasa Sist. Ind., Vol. 10, No. 1, Pp. 1-14, 2021, Doi: 10.26593/Jrsi.V10i1.4271.1-14.

[14] V. Amalia, D. Syamsuar, And L. Atika, "Komparasi Metode Wp Saw Dan Waspas Dalam Penentuan Penerima Beasiswa Penelusuran Minat Dan Kemampuan," J. Inform., Vol. 6, No. 1, Pp. 114-121, 2019, Doi: 10.31311/Ji.V6i1.5511. 